\title{
SLAUGYTOJŲ VEIKLA, TEIKIANT PAGALBA KARŠČIUOJANČIAM VAIKUI
}

\author{
Silva Kostyliovienė ${ }^{1,2}$, Liveta Mozūraitytè ${ }^{1,5}$, Alina Vaškelytė ${ }^{1,3}$, \\ Dovilè Grinkevičiūtè ${ }^{2,4}$, Regina Adomaitienè ${ }^{1}$ \\ ${ }^{1}$ Kauno kolegijos Medicinos fakulteto Slaugos katedra, ${ }^{2}$ Lietuvos sveikatos mokslu universiteto \\ ligoninès Kauno kliniku Vaiku intensyviosios terapijos skyrius, \\ ${ }^{3}$ Lietuvos sveikatos mokslu universiteto Slaugos fakulteto Slaugos ir rūpybos katedra, \\ ${ }^{4}$ Lietuvos sveikatos moksly universiteto Medicinos fakulteto Vaiku ligu klinika, \\ ${ }^{5}$ Lietuvos sveikatos mokslu universiteto ligoninès Kauno kliniku Anesteziologijos klinika
}

Raktažodžiai: vaikas, karščiavimas, slaugytojo veikla, skubi pagalba karščiavimo metu.
Santrauka
Kūdikių ir ankstyvojo amžiaus vaikų karščiavimo atveju teikiant pagalbą, vienas iš svarbiausių svei- katos priežiūros komandos narių yra slaugytojas. Tai sveikatos priežiūros specialistas, kuris turi ne tik at- pažinti, bet ir gebėti îvertinti karščiuojančio vaiko būklę, laiku pastebėti jos pokyčius, profesionaliai ir kokybiškai slaugyti, žinoti, kokią informaciją teikti tèvams, kaip juos įtraukti ị slaugos procesą, kokie galimi nemedikamentiniai gydymo būdai, saugios antipiretikų vartojamosios dozès ir galimas šalutinis poveikis. Turèdamas tinkamų žinių ir profesionaliai teikdamas pagalbą karščiuojančiam vaikui, slaugy- tojas padès jam greičiau pasveikti ar sumažins karš- čiavimą.
Tikslas - atskleisti slaugytojų žinias ir veiklą, teikiant pagalbą karščiuojančiam vaikui.
Tyrimas vyko nuo 2018 m. lapkričio 7 iki gruodžio 3 dienos Lietuvoje veikiančių universitetinès $(\mathrm{X})$, klinikinès $(\mathrm{Y})$ ir rajono $(\mathrm{Z})$ ligoninių intensyvio- sios terapijos (ITS) ir prièmimo-skubiosios pagalbos (PSPS) skyriuose. Tyrime pakviesti dalyvauti visi pasirinktųų skyrių slaugytojai, dirbantys su vaikais skirtingo tipo ligoninèse. Atlikta slaugytojų anoni- minė anketinė apklausa. Išdalintos 105 anketos, iš kurių grąžintos tinkamos analizei 82, atsako dažnis - 78,09 procentai.
Tyrimo rezultatai atskleide, jog didžioji dalis ap- klaustųjų dèmesi skiria karščiuojančio vaiko būklès pokyčių: kvėpavimo, kūno temperatūros, sąmonės,

dehidratacijos nustatymui ir vertinimui, teikia informaciją karščiuojančio vaiko tėvams, žino, kad antipiretikai vaikams skiriami pagal jų svorị ir amžių, tačiau mažiau nei pusė, vertindami karščiuojančio vaiko būklę, vertintų kraujotakos sutrikimus, oro patekimą i plaučius, informuotų tèvus, kaip elgtis, ivvykus traukuliams, kaip atpažinti neblykštantị bėrimą. Maža dalis apklaustujų atsakè, kad rekomenduotų tèvams karščiuojanti vaiką ištrinti kempinèle, suvilgyta alkoholiu. Dauguma slaugytojų, dirbančių PSPS, žino ir tèvams patartų skatinti vaiką išgerti reikiamą skysčių kiekị, atsižvelgiant i jo amžių, informuotų apie blogèjančios būklès požymius, paklaustų tėvų, ar suprato informaciją. Tik apie pusè tyrimo dalyvių, vertindami karščiuojančio vaiko būklę, vertintų odos, lūpų spalvą, sąmonę, išsamiai informuotų tẻvus apie tinkamą antipiretikų dozę, o maža dalis rekomenduotų tėvams karščiuojantị vaiką ištrinti kempinèle, suvilgyta alkoholiu. Dauguma slaugytojų, dirbančių ITS, vertindami karščiuojančio vaiko gyvybei pavojingus požymius, vertintų kvėpavimą ir kraujotaką, tẻvams pabrèžtų tinkamos antipiretikų dozès parinkimo svarbą ir skysčių vartojimo naudą, atsižvelgiant i jų poreiki pagal amžių, informuotų tèvus apie blogèjančios būklès požymius, tačiau mažiau nei pusė vertintų pasunkejjusị oro patekimą ị plaučius ir sąmonės būklę, nė viena nerekomenduotų karščiuojančio vaiko ištrinti kempinėle, suvilgyta alkoholiu.

\section{Ivadas}

Kūdikių ir ankstyvojo amžiaus vaikų karščiavimas yra viena dažniausių priežasčių, dẻl kurios kreipiamasi ị sveikatos priežiūros specialistus. Tai antra pagal dažnumą prie- 
žastis, dèl kurios vaikas patenka ị ligoninę [1]. Lietuvoje apie pusę ligonių, atvykstančių i PSPS, sudaro 3-6 mėnesių kūdikiai, iš kurių 15-25 proc. karščiuojantys [2]. Mokslinių tyrimų rezultatai atskleidžia, kad tai didelio masto problema [3], kelianti nerimą ir vaiko tėvams (57,0 proc.), ir sveikatos priežiūros specialistams: gydytojams (14,0 proc.) bei slaugytojoms (36,0 proc.) [4]. Karščiavimo metu pagreiteja medžiagų apykaita (metabolizmas), deguonies $\left(\mathrm{O}_{2}\right)$ sunaudojimas, kraujotaka [5], o karštiniai traukuliai (KT) gali padidèti net iki 2-3 k./min. [3]. Vertindama karščiuojančio vaiko kraujotakos stabilumą, slaugytoja turi nuolatos stebèti ir vertinti visus centrinès hemodinamikos rodiklius: širdies susitraukimų dažnį (ŠSD), kapiliarų prisipildymo laiką (KPL), pulsą (periferinị ir centrinị), arterinị kraujospūdị (AKS) $[1,2]$. Vertindama centrinès nervų sistemos (CNS) veiklą, slaugytoja turètų stebèti karščiuojančio vaiko sąmonę, kuri sutrinka, i̇vykus KT [3]. Nacionalinio sveikatos ir klinikinès kompetencijos instituto (angl. National institute for health and clinical excellence, NICE) ir Karališkosios slaugos kolegijos (angl. Royal college of nursing, RCN) rekomendacijose pabrěžiama, kad ir gydytojai, ir slaugytojai turi suvokti, įsidèmèti bei tẻvams paaiškinti, kad temperatūrą mažinančios priemonès nemažina $\mathrm{KT}$ rizikos ar jų dažnio $[6,7]$, todèl neturètų būti naudojamos šiam tikslui. Sveikatos priežiūros specialistai turi mokyti tèvus elgtis, prasidejus KT. NICE rekomendacijose sveikatos priežiūros specialistams (2007) skelbiama, kad karščiuojančio vaiko dehidratacijos požymiai turi būti reguliariai vertinami kartu su kitais rodikliais [6,7].

Pasak Abu Zubeden ir kt. (2016), būtent slaugytojai atlieka išsamų karščiuojančio vaiko ištyrimą ir, juo remdamiesi, turi priimti pagrịstą sprendimą [8]. NICE (2013) rekomendacijose pateikiama ,„̌ingsnių“ sistema, kuri sveikatos priežiūros specialistams padeda ịvertinti karščiuojančiu kūdikių ar vaikų iki 5-erių metų būklę [6]. Žengiant šiuos žingsnius, turi būti nustatomas vaiko kūno temperatūros laipsnis, antipiretikų paskyrimas ir vartojimas pagal gydytojo nurodymus, vèliau ieškoma karščiavimo priežasties ir įvertinami simptomai ar požymiai, kurie leidžia nustatyti sunkios ligos vystymąsi. NICE ir RCN rekomendacijose nurodoma, kad siekiant tinkamai ịvertinti karščiuojančio vaiko būklę, vertinimą reikia atlikti reguliariai keletą kartų ir tam skirti pakankamai laiko [6, 7].

E. Purssell (2013) teigia, kad karščiuojančio vaiko komforto užtikrinimui bei greitesniam būklès atkūrimui reikšmès turi tėvų žinios ir suvokimas, ne tik gydytojo paskirtas medikamentinis gydymas [9]. Danijoje (2016) atlikto tyrimo rezultatai atskleidė nepakankamas tėvų žinias apie vaikų karččiavimą ir galimas jo pasekmes. Tik 1 iš 15 šiame tyrime dalyvavusių tèvų žinojo, kad esant $40^{\circ} \mathrm{C}$ kūno temperatūrai, pažeidžiamos vaiko smegenys [10].
Bendrosios praktikos slaugytojo (BPS) veiklą mūsų šalyje reglamentuoja Lietuvos medicinos norma MN 28:2019. Joje nurodytos BPS teisès, pareigos, kompetencija ir atsakomybė. Šiuo dokumentu slaugytojas privalo vadovautis, teikdamas slaugos paslaugas karščiuojančiam vaikui. Teikdamas būtinają medikamentinę pagalbą, BPS savarankiškai gali skirti kai kuriuos antipiretikus ir prieštraukulinius vaistus [11]. Slaugytojai, PSPS teikiantys slaugos paslaugas, turi būti išklausę pacientų medicininio rūšiavimo skubiosios pagalbos skyriuje kursą [12], kad gebètų atskirti karščiuojančius vaikus, kuriems pagalbos reikia nedelsiant, nuo tų, kurių būklè yra stabili ir pagalba gali būti suteikiama šiek tiek vẻliau.

Slaugytojas turi gebetti ịvertinti karščiuojančio vaiko būklę, laiku pastebėti jos pokyčius, profesionaliai ir kokybiškai slaugyti, žinoti, kokią informaciją teikti tèvams, kaip juos itraukti ị slaugos procesą, kokie galimi nemedikamentiniai gydymo būdai, kokios yra saugios antipiretikų vartojamosios dozès bei galimas šalutinis poveikis [6]. Turėdamas tinkamų žinių ir profesionaliai teikdamas pagalbą karščiuojančiam vaikui, slaugytojas gali padèti greičiau pasveikti ar net išgelbèti gyvybę. Kai kurių mokslinių tyrimų rezultatai atskleidžia, kad ne visi slaugytojai turi pakankamai žinių apie vaikų karščiavimą [13, 14], o jų žinių stoka ir nenuoseklus požiūris lemia netinkamą karščiuojančių vaikų priežiūrą ir gali tėvams sukelti karščiavimo fobiją [13].

Darbo tikslas - atskleisti slaugytojų žinias ir veiklą, teikiant pagalbą karščiuojančiam vaikui.

\section{Tyrimo medžiaga ir metodai}

Tyrimas vyko nuo $2018 \mathrm{~m}$. lapkričio 7 iki gruodžio 3 dienos Lietuvos universitetinès $(\mathrm{X})$, klinikinès $(\mathrm{Y})$ ir rajono (Z) ligoninių intensyviosios terapijos (ITS) ir priemimo-skubiosios pagalbos (PSPS) skyriuose. Tyrime buvo pakviesti dalyvauti visi pasirinktujų ligoninių ITS ir PSPS slaugytojai, dirbantys su vaikais. Atlikta slaugytojų anoniminè anketinė apklausa. Išdalintos 105 anketos, iš kurių grįžo ir tinkamos analizei buvo 82, atsako dažnis - 78,09 procentai.

Respondentai pagal amžiaus grupes: $25-35 \mathrm{~m}$. sudare penktadali, 36- 49 m. $-35,4$ proc., $50-60 \mathrm{~m}$. $-35,4$ proc. ir per 60 metų - 36,1 proc. Kiek daugiau nei pusè (54,9 proc.) respondentu išsimokslinimą igijo medicinos mokyklose, beveik trečdalis $(30,5$ proc.) turèjo aukštaji neuniversitetini, dešimtadalis (11 proc.) universitetinị išsimokslinimą ir tik maža dalis ( 3,7 proc.) nurode turintys slaugos magistro laipsnị. Didžioji dalis respondentų ( 75,6 proc.) turejjo daugiau nei dešimtị metų klinikinio darbo patirties.

Tyrimo duomenims rinkti buvo naudojamas šio darbo autorių sukurtas klausimynas, kuriame pateikti 23 klausimai ir penkios klinikinès situacijos. Siekta nustatyti respondentų atliekamus veiksmus, priimamus sprendimus, teikiant pagalbą karščiuojančiam vaikui. Atsakymų variantai patei- 
kiami pagal Likerto (Likert) skalę nuo „visiškai sutinku“ iki „visiškai nesutinku“.

Rezultatų analizei ir duomenų apibendrinimui naudotos aprašomosios statistikos skaitinès charakteristikos: vidurkis, standartinis nuokrypis, pasiskirstymas dažniais (procentine išraiška). Esant nenormaliam pasiskirstymui tarp dviejų grupių, buvo taikomas Mano Vitney (Mann-Whitney) testas, daugiau nei dviem grupems - Kruskalio Voliso (KruskalWallis) testas. Esant normaliam pasiskirstymui tarp dviejų grupių, buvo taikomas t testas arba Stjudento (Student) testas, kai grupių buvo daugiau nei dvi - ANOVA testas. Kokybinių požymių statistinis ryšys buvo tiriamas susietų lentelių metodu. Remiantis lentelių duomenimis, apskaičiuota chi kvadrato $\left(\chi^{2}\right)$ reikšmė, laisvès laipsnių skaičius (lls). Rezultatai laikyti statistiškai patikimais, kai statistinio reikšmingumo tėvams. Kiek daugiau nei dešimtadalis $(11,9$ proc.) universitetinès ligoninès slaugytojų visą informaciją užrašytų ant lapelio, duotų lankstinuką su informacija apie gydytojo paskirtą vaistą, tačiau jei ir tada karščiuojančio vaiko tẻvams būtų neaišku, patartų vèl kreiptis ị gydytoją (1 pav.).

Statistiškai reikšmingai didesnè dalis Y (klinikinės) ligoninès PSPS dirbančiu tyrimo dalyvių, lyginant su X (universitetinès) ir Z (rajono) ligoninių PSPS slaugytojomis, informuotų tèvus apie galimą šalutini poveikị, perdozavus paracetamolio (acetaminofeno) (Y PSPS-100 proc., Z PSPS60,0 proc., X PSPS-36,0 proc.; $\mathrm{p}<0,0001$ ), paklaustų, ar viską suprato (Y PSPS-100 proc., Z PSPS-60,0 proc., X PSPS-60,0 proc.; $\mathrm{p}=0,01)$.

Nè viena $(0,0$ proc.) $\mathrm{X}$ ir Y ligoninių PSPS slaugytoja nesiųstų karščiuojančio vaiko tèvų kartotinei gydytojo konsul- koeficientas $p<0,05$.

Tyrimui atlikti gautas Lietuvos sveikatos mokslų universiteto Bioetikos centro pritarimas Nr. BEC-KK(B)-05.

\section{Rezultatai}

Tyrimo metu siekta išsiaiškinti, kokius veiksmus atlieka slaugytojai, kai ị juos kreipiasi karščiuojančio vaiko tèvai, nežinantys, kokią dozę paracetamolio galima duoti vaikui ir kokia didžiausia paros dozè. Analizuojant tyrimo rezultatus, paaiškejjo, kad visos klinikinejje ligoninèje (100,0 proc.) ir didžioji dauguma universitetinèje ligoninèje ( 85,7 proc.) dirbančių slaugytojų išsamiai paaiškintų tèvams, kad, priklausomai nuo vaiko svorio, jis gali išgerti $250-375 \mathrm{mg}$, o daugiausia per parą - $2000 \mathrm{mg}$, tačiau taip darytų statistiškai reikšmingai mažesnè dalis (39,1 proc.) rajono ligoninèje dirbančių slaugytojų ( $<<0,001)(1$ pav.). Šioje situacijoje informuotų apie galimą paracetamolio šalutini poveikị perdozavus ir karščiuojančio vaiko tèvų paklaustų, ar teisingai suprato, visos (100,0 proc.) klinikinejje ligoninejje dirbančios slaugytojos, tačiau taip darytų tik apie puse (52,2 proc.) rajono ligonineje ir 47,6 proc. universitetinejje ligoninèje dirbančių tyrimo dalyvių ( $\mathrm{p}=0,001)$ (1 pav.). Beveik trečdalis (26,1 proc.) rajono ligoninès slaugytoju teigè, kad tèvus nusiųstų kartotinès informacijos pas gydytoją, tačiau taip elgtųsi tik labai maža dalis universitetinès $(2,4$ proc.) ir nè viena klinikinès $(0,0$ proc.) ligoninès slaugytoja $(\mathrm{p}=0,002)(1 \mathrm{pav}$.$) . Be-$ veik trečdalis (26,1 proc.) respondentų, dirbančių rajono ligoninèje, tokioje situacijoje pirmiausia pasitikslintų gydytojo paskyrimų lape, kartu su gydytoju patikslintų paskirto medikamento dozę ir tik tuomet viską paaiškintų karščiuojančio vaiko

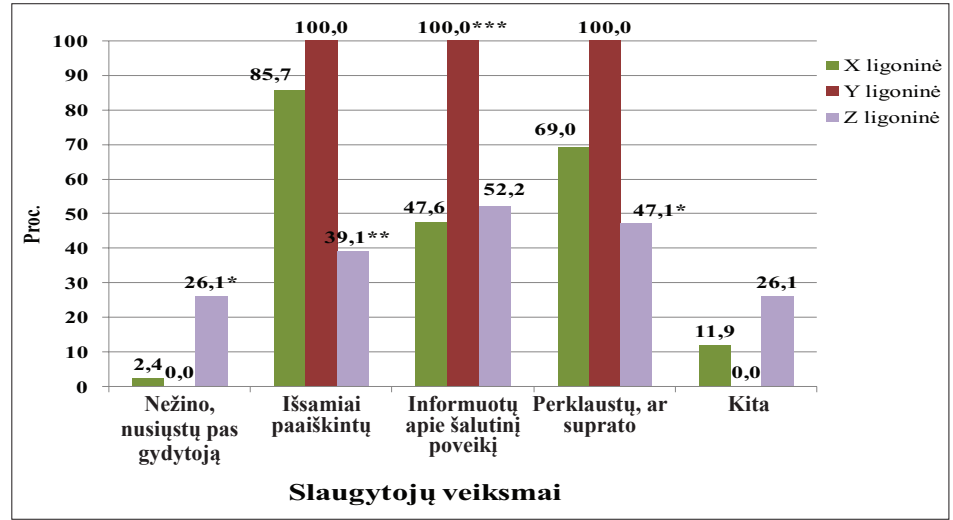

1 pav. Slaugytojų veiksmai, karščiuojančio vaiko tèvams nesupratus informacijos apie vaistų vartojimą.

${ }^{*} p=0,002$, lyginant $X$ ir $Y$ ligoninese; $* * p<0,0001$, lyginant X ir Y ligoninèse; $* * * p=0,001$, lyginant $X$ ir $Z$ ligoninèse.

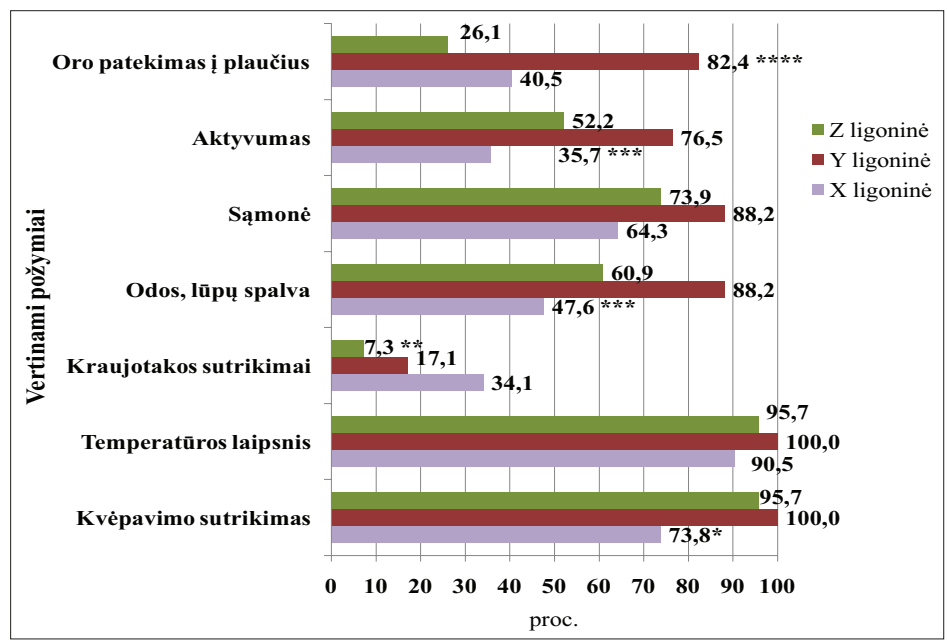

2 pav. Slaugytojų vertinami karščiuojančio vaiko požymiai. ${ }^{*} p=0,009$, lyginant $Y$ ir $Z$ ligonines; ** $p=0,001$, lyginant $X$ ir $Y$ ligonines; $* * * p=0,02$ lyginant $X$ ir $Y$ ligonines; $* * * * p=0,001$, lyginant $X$ ir $Z$ ligonines. 
tacijai, tačiau tai darytų pusė (50,0 proc.) Z ligoninės PSPS slaugytojų $(\mathrm{p}<0,0001)$. Statistiškai reikšmingai didesnè dalis $\mathrm{Y}$ ligoninės ITS dirbančių tyrimo dalyvių, lyginant su X ligoninès ITS ir Z ligoninès ITS slaugytojomis, išsamiai paaiškintų tėvams, kad pagal vaiko svorị, jis gali išgerti paracetamolio (acetaminofeno) 250 - $375 \mathrm{mg}$, o daugiausia per parą $2000 \mathrm{mg}$; paklaustų tèvų, ar tikrai suprato (Y ITS - 100 proc., X ITS $-82,4$ proc., Z ITS $-36,0$ proc.; $p=0,03$ ).

Tyrimo metu siekta nustatyti, ar slaugytojai žino, kokie yra gyvybei grèsmingi požymiai ir kokius karščiuojančio vaiko požymius pirmiausia reiketų ịvertinti. Išanalizavus tyrimo rezultatus, paaiškèjo, kad slaugytojai pirmiausia ịvertintų ne tik karščiuojančio vaiko gyvybei grèsmingus požymius (kvėpavimą, kraujotaką, sąmonę), bet ir tokius, kaip kūno temperatūra, odos, lūpų ar liežuvio spalva, aktyvu-

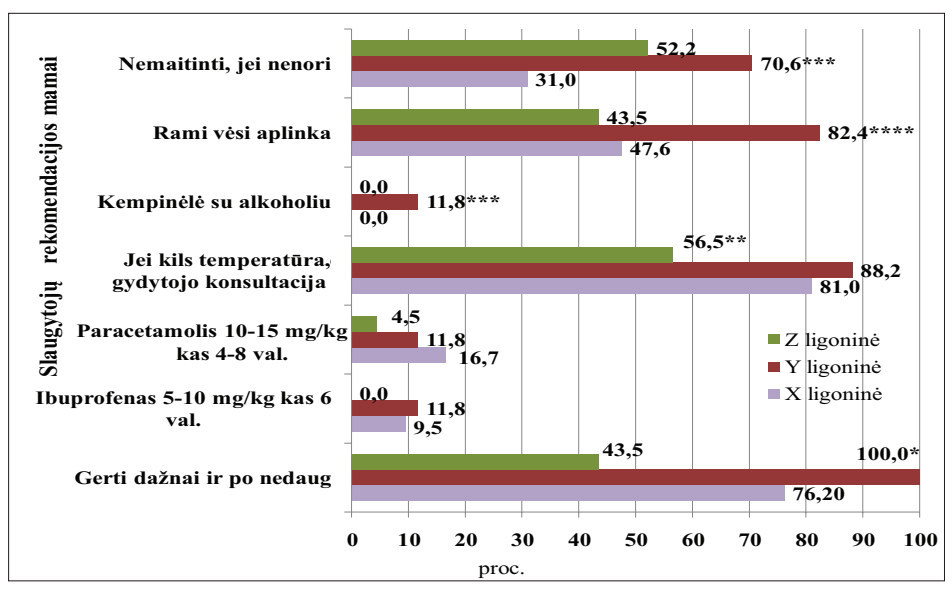

3 pav. Slaugytojų rekomendacijos karščiuojančio vaiko mamai.

${ }^{*}<0,0001$, lyginant su $X$ ir $Z$ ligoninemis; ${ }^{*} p=0,004$, lyginant su $Y$ ir $Z$ ligoninemis;

${ }^{* * *} p=0,002$, lyginant su $X$ ir Y ligoninemis; ${ }^{* * * *} p=0,003$, lyginant su $Y$ ir $Z$ ligoninemis.

1 lentelè. Slaugytojų rekomenduojami veiksmai karščiuojančio kūdikio mamai.

\begin{tabular}{|c|c|c|c|c|c|c|c|}
\hline \multicolumn{3}{|c|}{ Darbo vieta - ITS } & \multirow{2}{*}{\multicolumn{2}{|c|}{ Rekomenduojami veiksmai }} & \multicolumn{3}{|c|}{ Darbo vieta - PSPS } \\
\hline X lig. & Y lig. & Z lig. & & & Y lig. & Z lig. & $\mathrm{X}$ lig. \\
\hline 52,9 & 100,0 & $23,1 *$ & \multicolumn{2}{|c|}{ Dažnai duoti vaikui gerti nedidelị kiekį skysčių } & 92,0 & 100,0 & $70,0^{*}$ \\
\hline 0,0 & 0,0 & 0,0 & \multicolumn{2}{|c|}{ Sugirdyti ibuprofeno (5-10 mg/kg, kas 6 val.) } & 16,0 & 12,5 & 0,0 \\
\hline 17,6 & 0,0 & 7,7 & \multicolumn{2}{|c|}{$\begin{array}{l}\text { Sugirdyti paracetamolio (10-15 mg/kg kas } 4-8 \\
\text { val. iki } 5 \text { dozių) }\end{array}$} & 16,0 & 12,5 & 0,0 \\
\hline 82,4 & 100,0 & $30,8 * *$ & \multicolumn{2}{|c|}{ Jeigu temperatūra kils, kreiptis ị gydytoją } & 80,0 & 87,5 & 90,0 \\
\hline 0,0 & 0,0 & 0,0 & \multicolumn{2}{|c|}{ Aprengti kuo šilčiau } & 0,0 & 0,0 & 0,0 \\
\hline 0,0 & 0,0 & 0,0 & \multicolumn{2}{|c|}{ Kūną ištrinti kempinėle, suvilgyta alkoholiu } & 0,0 & 12,5 & 0,0 \\
\hline 41,2 & 100,0 & 23,1 & \multicolumn{2}{|c|}{ Sudaryti ramią, vėsią $\left(+18^{\circ} \mathrm{C}\right)$ aplinką } & 52,0 & 81,3 & 70,0 \\
\hline 41,2 & 100,0 & 23,1 & \multicolumn{2}{|c|}{$\begin{array}{l}\text { Nemaitinti, jeigu vaikas } \\
\text { nenori }\end{array}$} & $16,0^{* * *}$ & 68,8 & 70,0 \\
\hline \multicolumn{4}{|c|}{$\begin{array}{l}* \mathrm{p}=0,01, \text { lyginant X VPSPS ir Y VPSPS } \\
* * \mathrm{p}=0,03 \text {, lyginant X VPSPS ir Y VPSPS }\end{array}$} & \multicolumn{4}{|c|}{$\begin{array}{l}* \mathrm{p}=0,004, \text { lyginant X VPSPS ir Y VPSPS } \\
* * \mathrm{p}=0,001 \text {, lyginant Y VPSPS ir Z PSPS }\end{array}$} \\
\hline
\end{tabular}

mas. Visi (100,0 proc.) Y ligoninès ir didžioji dauguma (95,7 proc.) Z ligoninès slaugytojų ịvertintų karščiuojančio vaiko kvépavimą, tuo tarpu tai vertintų tik apie trys ketvirtadaliai ( 73,8 proc.) X ligoninės slaugytojų ( $\mathrm{p}=0,009)$ ( 2 pav.).

Karččiuojančio vaiko kraujotakos sutrikimus vertintų apie trečdalis $(34,1$ proc.) $\mathrm{X}$, apie penktadalis $(17,1$ proc.) $\mathrm{Y}$ ir mažiau nei dešimtadalis ( 7,3 proc.) $\mathrm{Z}$ ligoninejje dirbančių tyrimo dalyvių ( $\mathrm{p}=0,001)$ ( 2 pav.).

Karščiuojančio vaiko sąmonę, kaip gyvybei grèsmingą požymi, ịvertintų didesnè dalis $(76,5$ proc.) Y, apie pusė $\mathrm{Z}(52,2$ proc.) ir kiek daugiau nei trečdalis $(35,7$ proc.) $\mathrm{X}$ ligoninèje dirbančių apklaustujų ( $\mathrm{p}=0,02)(2$ pav.).

Tik apie trečdalis (26,1 proc.) slaugytojų, dirbančių Z ligoninejje, nurodè, kad karščiuojančiam vaikui vertintu oro patekimą i plaučius. Tai darytų beveik puse (40,5 proc.) X ir didesnè dalis $(82,4$ proc.) Y ligoninèje dirbančių slaugytojų $(\mathrm{p}=0,001)(2 \mathrm{pav}$.$) .$

Atsižvelgiant ị PSPS slaugytojų darbo vietą, statistiškai reikšmingai daugiau slaugytojų, dirbančių $\mathrm{Y}$ ir X ligoninių ITS, lyginant su Z ligoninès ITS, vertindami karščiuojančio vaiko būklę, kaip grèsmingą požymį ịvertintų pasunkejjusị oro patekimą i plaučius (Y PSPS - 87,5 proc., X PSPS - 44,0 proc., Z PSPS - 10,0 proc.; $\mathrm{p}<0,0001)$, kraujotakos sutrikimus (Y PSPS $-81,3$ proc., X PSPS $-68,0$ proc., Z PSPS - 10,0 proc.; $p=0,001$ ), odos, liežuvio ar lūpų spalvą (Y PSPS - 43,8 proc., X PSPS - 34,4 proc., Z PSPS $-21,9$ proc.; $p=0,02$ ).

Statistiškai reikšmingai mažiau slaugytojų, dirbančių X ligoninès PSPS, lyginant su Y ir Z ligoninių PSPS slaugytojais, vertintų karščiuojančio vaiko kvėpavimo sutrikimus (X PSPS - 76,0 proc., Y PPSP - 100, 0 proc., Z PSPS - 100,0 proc.; $p=0,03$ ), sąmonę (X PSPS - 44,0 proc., Y PSPS -87,5 proc., Z PSPS 50,0 proc.; $\mathrm{p}=0,02$ ), aktyvumo lygi (X PSPS - 28,0 proc., Y PSPS - 81,3 proc., Z PSPS $-70,0$ proc.; $\mathrm{p}=0,002$ ).

Tyrimo metu siekta nustatyti, kokius veiksmus atlieka slaugytojai, kai mama informuoja, jog jos penkių mènesių kūdikis atrodo silpnas, nesidomi aplinka, nenori žaisti, irzlus, atsisako valgyti. Mamai pamatavus kūdikio kūno temperatūrą pažastyje, termometras parodė $37,7^{\circ} \mathrm{C}$. Tyrimo rezultatai parodè, kad visos (100 
proc.) $\mathrm{Y}$ ir didesne dalis (76,2 proc.) $\mathrm{X}$ ligoninèje dirbančiu slaugytoju šioje situacijoje mamai patartu dažnai vaikui duoti nedideli kieki skysčiu, tuo tarpu taip patartu tik mažiau nei pusè $(43,5$ proc.) $\mathrm{Z}$ ligoninès slaugytojų $(\mathrm{p}<0,001)$ ( 3 pav.).

Didžioji dalis $\mathrm{Y}(88,6$ proc.) ir X ( 81,0 proc.) ligoninèse dirbančiu tyrimo dalyvių rekomendavo mamai, kylant vaiko temperatūrai, kreiptis ị gydytoją, tuo tarpu taip elgtis patare tik apie pusè $(56,5$ proc.) $\mathrm{Z}$ ligoninès slaugytojų $(\mathrm{p}=0,04)$. Kiek daugiau nei dešimtadalis (11,8 proc.) Y ligoninės slaugytojų mamai rekomenduotų vaiko kūną ištrinti kempinėle, suvilgyta alkoholiu, tačiau to nerekomendavo nè vienas $\mathrm{Z}$ ir $X$ ligoninių slaugytojas $(\mathrm{p}=0,02)$. Didesnè dalis $(82,4$ proc.) Y, apie pusè (47,6 proc.) X, 43,5 proc. Z ligoninèse dirbančiu slaugytojų rekomenduotų mamai suteikti vaikui ramią, vèsią $\left(+18{ }^{\circ} \mathrm{C}\right)$ aplinką $(\mathrm{p}=0,03)(3$ pav. $)$.

Atsižvelgiant ị slaugytojų darbo vietą PSPS, statistiškai reikšmingai mažiau slaugytojų, dirbančių X ligoninès PSPS, lyginant su Y ir Z ligoninių PSPS slaugytojų nuomone, patartų mamai vaiko nemaitinti, jei jis nenori (X PSPS - 16,0 proc., Y PSPS $-68,8$ proc., Z PSPS $-70,0$ proc.; $\mathrm{p}=0,001$ ) (1 lentelè).

Statistiškai reikšmingai daugiau slaugytojų, dirbančių X ir Y ligoninių PSPS, lyginant su slaugytojų, dirbančių Z ligoninès PSPS, patartų mamai karščiuojančiam vaikui duoti daugiau skysčiu (X PSPS - 92,0 proc., Y PPSP - 100 proc., Z PSPS $70,0$ proc.; $p=0,04)$. Apie dešimtadalis $(12,5$ proc.) $\mathrm{Y}$ ligoninès PSPS slaugytojų mamai patartu vaiko kūną ištrinti kempinėle, suvilgyta alkoholiu (1 lentelè).

Statistiškai reikšmingai didesne dalis $\mathrm{Y}$ ir $\mathrm{X}$ ligoninių ITS dirbančių tyrimo dalyvių, lyginant su $\mathrm{Z}$ ligoninès ITS slaugytojų nuomone, patartų mamai duoti karščiuojančiam kūdikiui dažnai gerti nedidelị kiekị skysčiu (Y ITS - 100,0 proc., X ITS - 52,9 proc., Z ITS - 23,1 proc.; $\mathrm{p}=0,01)$ (1 lentelè).

Siekta nustatyti, kokius medikamentus slaugytojai naudotų, mažindami temperatūrą jaunesniam kaip 3 mènesių kūdikiui. Rezultatų analizé parodé, kad šiek tiek daugiau nei trys ketvirtadaliai (76,5 proc.) $\mathrm{Y}$ ir dau- giau nei pusė $(52,4$ proc.) X ligoninėse dirbančių apklaustuju tokio amžiaus kūdikio temperatūrai mažinti naudotu paracetamoli (acetaminofena) $(10-15 \mathrm{mg} / \mathrm{kg} \mathrm{kas} 4-8$ val., iki 5-iu doziu), tačiau toki vaistą ir dozę naudotu tik kiek mažiau nei penktadalis (17,4 proc.) Z ligoninès slaugytojų $(p=0,02)(4$ pav. $)$.

Kiek mažiau nei pusè (39,1 proc.) Z ligoninès slaugytojų nurodè, kad jaunesnio kaip 3 mèn. kūdikio temperatūrą mažintų mažesne paracetamolio (acetaminofeno) doze (5-10 $\mathrm{mg} / \mathrm{kg}$ kas 6 val.), tačiau tokị pat vaistą ir dozę naudotų tik kiek mažiau nei penktadalis X (19,0 proc.) ir Y (17,6 proc.) ligoninèse dirbančių slaugytojų $(\mathrm{p}=0,02)$ (4 pav.).

Atsižvelgiant ị slaugytojų darbo vietą PSPS, statistiškai

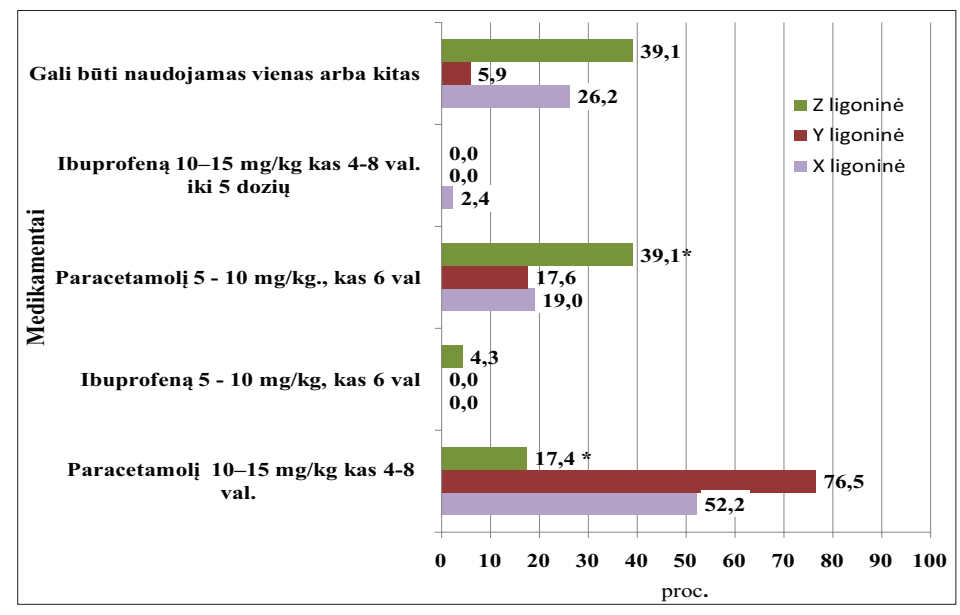

4 pav. Slaugytojų pasirenkami medikamentai mažinti jaunesnio kaip 3 mèn. kūdikio temperatūrą.

${ }^{*} p=0,02$, lyginant su $X$ ir Y ligoninemis.

2 lentelè. Slaugytojų teikiama informacija tėvams, ị namus išsivežantiems karščiuojantị vaiką.

\begin{tabular}{|c|c|c|c|c|c|c|c|}
\hline \multicolumn{3}{|c|}{ Darbo vieta - ITS } & \multirow{2}{*}{\multicolumn{2}{|c|}{ Teikiama informacija }} & \multicolumn{3}{|c|}{ Darbo vieta - PSPS } \\
\hline $\mathrm{X}$ lig. & Y lig. & Z lig. & & & X lig. & Y lig. & Z lig. \\
\hline 70,6 & 100,0 & 38,5 & \multicolumn{2}{|c|}{$\begin{array}{l}\text { Apie gydytojo paskirtų antipiretikų galimą šalutinị } \\
\text { poveikị }\end{array}$} & $48,0 *$ & 75,0 & 90,0 \\
\hline $65,4 *$ & 3,8 & 30,8 & \multicolumn{2}{|c|}{ Apie gydytojo paskirtų vaistų tinkamą vartojimą } & 80,0 & 100,0 & 90,0 \\
\hline 94,1 & 100,0 & 61,5 & \multicolumn{2}{|c|}{ Apie per parą rekomenduojamų išgerti skysčių kiekį } & 88,0 & 100,0 & 90,0 \\
\hline 64,7 & 100,0 & $15,5 * *$ & \multicolumn{2}{|c|}{ Apie dehidratacijos požymius } & 80,0 & 93,8 & 90,0 \\
\hline 52,9 & 100,0 & 30,8 & \multicolumn{2}{|c|}{ Apie dehidratacijos požymių atpažinimą } & 52,0 & 75,0 & 40,0 \\
\hline 52,9 & $100,0^{*}$ & $15,4 * * *$ & \multicolumn{2}{|c|}{ Apie neblykštančio bėrimo atpažinimą } & 48,0 & 100,0 & $20,0 * *$ \\
\hline 64,7 & 100,0 & 46,2 & \multicolumn{2}{|c|}{$\begin{array}{l}\text { Apie būklès blogėjimo požymių atpažinimą tinkamu } \\
\text { laiku }\end{array}$} & 88,0 & 93,8 & 100,0 \\
\hline 70,6 & 100,0 & 23,1 & \multicolumn{2}{|c|}{ Apie elgesi, ịvykus traukuliams } & 88,0 & 100,0 & 70,0 \\
\hline 29,4 & 100,0 & 0,0 & \multicolumn{2}{|c|}{ Apie neigiamas karščiavimo pasekmes } & $52,0 * * *$ & 87,5 & 90,0 \\
\hline \multicolumn{4}{|c|}{$\begin{array}{l}* p=0,02, \text { lyginant } Y \text { VITS ir Z VITS } \\
* * p=0,01, \text { lyginant X VITS ir Y VITS } \\
* * * p=0,05, \text { lyginant X VITS ir Y VITS }\end{array}$} & \multicolumn{4}{|c|}{$\begin{array}{l}* p=0,04, \text { lyginant } Y \text { VITS ir Z VITS } \\
* * p<0,0001, \text { lyginant X VITS ir Y VITS } \\
* p=0,02, \text { lyginant Y VITS ir Z VITS }\end{array}$} \\
\hline
\end{tabular}


reikšmingai mažiau slaugytojų, dirbančių Z ligoninės PSPS, lyginant su X ir Y ligoninių PSPS slaugytojomis, kūdikio temperatūrai mažinti naudotų paracetamolị (acetaminofeną) po $10-15 \mathrm{mg} / \mathrm{kg}$ kas 4-8 val., iki 5-ių dozių (X PSPS - 48,0 proc., Y PPSP $-48,0$ proc., Z PSPS $-4,0$ proc.; $\mathrm{p}=0,003$ ).

Atvejais, kai ị sveikatos priežiūros ịstaigą kreipiasi pagalbos tėvai dvejų metų vaikui, kurio pažastyje pamatuota kūno temperatūra yra $39{ }^{\circ} \mathrm{C}$, turinčiam ịgimtą širdies ydą, imunosupresinès būklès, didžioji dalis slaugytojų (X ligoninè - 90,5 proc.; Y ligoninè - 100,0 proc.; Z ligoninè - 100,0 proc.) teigé, kad tokiam vaikui pagalbą teiktų nedelsiant, nes būtina nustatyti gyvybei grèsmingus požymius, tikslų kūno temperatūros laipsnị, užtikrinti ramią ir vèsią $\left(+18{ }^{\circ} \mathrm{C}\right)$ aplinką bei kuo skubiau informuoti gydytoją.

Analizuota, kokią informaciją slaugytojai suteikia tèvams, kurie karščiuojantị vaiką išsiveža ị namus. Nustatyta, kad didesne dalis tyrime dalyvavusių slaugytojų tėvams paaiškintų gydytojo paskirtų antipiretikų galimą šalutini poveiki, kaip tinkamai vartoti gydytojo paskirtus medikamentus, kokị skysčių kiekị vaikas, atsižvelgiant ị amžių, turètų išgerti, $\mathfrak{i}$ kokius simptomus atkreipti demesį, norint laiku pastebèti būklès blogejjimo požymius. Statistiškai reikšmingai didesnė dalis (76,5 proc.) $\mathrm{Y}$ ir pusė (52,4 proc.) $\mathrm{X}$ ligoninèse dirbančių apklaustųų, lyginat su $\mathrm{Z}$ ligoninès slaugytojais ( 34,8 proc.), paaiškintų tèvams, kaip atpažinti dehidratacijos požymius $(\mathrm{p}=0,03)$, kaip nustatyti neblykštanti bèrimą (X lig. $-25,6$ proc.; Y lig. $-20,7$ proc.; $Z$ lig. $-4,9$ proc.; $\mathrm{p}<0,0001$ ), kaip elgtis, ivykus traukuliams (X lig. 41,5 proc.; Y lig. $-20,7$ proc.; $Z$ lig. $-14,6$ proc.; $p=0,0001$ ).

Atsižvelgiant ị slaugytojų darbo vietą PSPS, statistiškai reikšmingai daugiau slaugytojų, dirbančiu Z $Z$ ir Y ligoninių PSPS, lyginant su $X$ ligoninès PSPS slaugytojomis, informuotų tèvus apie neigiamą karščiavimo poveikị vaikui $(Z$ PSPS - 90,0 proc.; Y PSPS - 87,5,0 proc., X PPSP - 52,0 proc., $p=0,02)$, galimą gydytojo paskirtu antipiretikų šalutini poveiki (Z PSPS - 90,0 proc.; Y PSPS - 75,0 proc., X PSPS $-48,0$ proc., $\mathrm{p}=0,04$ ) (2 lentelè).

Reikšmingai didesnè dalis slaugytojų, dirbančių Y ligoninès PSPS, lyginant su X ir Z ligoninių PSPS slaugytojais, informuotų tèvus apie neblykštantị bèrimą (Y PSPS - 100,0 proc.; X PSPS - 48,0 proc., X PSPS - 20,0 proc., $\mathrm{p}<0,0001$ ) (2 lentelè).

Atsižvelgiant ị slaugytojų darbo vietą ITS, buvo nustatyta, kad reikšmingai didesnè dalis Y ir X ligoninių ITS slaugytojų, lyginant su Z ligoninès ITS slaugytojais, informuotu tèvus apie dehidratacijos požymius (Y ITS $-100,0$ proc., $\mathrm{X}$ ITS $-64,7$ proc., Z ITS - 15,4 proc.; $p=0,01$ ), patartu, kaip nustatyti neblykštantị bèrimą (Y ITS - 100,0 proc., X ITS 52,9 proc., Z ITS - 15,4 proc.; $\mathrm{p}=0,05$ ) (2 lentelè).

Reikšmingai didesnè dalis $\mathrm{X}$ ligoninès ITS slaugytojų, lyginant su Y ir Z ligoninių ITS slaugytojais, informuotų tèvus, kaip tinkamai vartoti gydytojo paskirtus vaistus (X ITS - 65,4 proc., Y ITS - 3,8 proc., Z ITS - 30,8 proc.; $\mathrm{p}=0,02)(2$ lentelè).

Tyrimo metu siekta išsiaiškinti slaugytojų nuomonę, ar karščiuojantis vaikas turètų vartoti antipiretikus ir didesnị skysčių kiekį? Slaugytojams buvo pateikta situacija apie pusès metų kūdikị, kurio temperatūra tiesiojoje žarnoje buvo $38,4{ }^{\circ} \mathrm{C}$. Kūdikis neramus, liguistas, nuolat griebiasi už ausies, skystos išmatos, sausos gleivinès, šiek tiek ịdubusios akys, vėsios galūnès. Rezultatų analizè parodè, kad statistiškai reikšmingai didesnès dalies $\mathrm{Y}(88,2$ proc.) ir $\mathrm{X}$ ( 85,7 proc.) ligoninėse dirbančių slaugytojų nuomone, lyginat su Z ligoninès slaugytojais (60,9 proc.), turètų būti vartojami gydytojo paskirti antipiretikai ir didesnis skysčių kiekis $(\mathrm{p}=0,001)$.

Atsižvelgiant ị slaugytojų darbo vietą ITS, nustatyta, kad reikšmingai didesne dalis $\mathrm{Y}$ ir X ligoninių ITS slaugytojų, lyginant su Z ligoninès ITS slaugytojais, teigè, kad kūdikiui turètų būti skiriami antipiretikai ir didesnis skysčių kiekis (Y ITS -100,0 proc., X ITS - 94,1 proc., Z ITS - 38,5 proc.; $\mathrm{p}=0,004)$.

Daugiau nei pusė Z ligoninès ITS slaugytojų atsakè nežinančios, nes vaiko būklę vertina ir sprendimus priima tik gydytojas, tuo tarpu taip nemano nè viena $\mathrm{Y}$ ir $\mathrm{X}$ ligoninių ITS slaugytojų (Y ITS - 0,0 proc., X ITS $-0,0$ proc., Z ITS $-61,5$ proc.; $\mathrm{p}=0,004)$.

\section{Diskusija}

Pasaulyje yra mokslo įrodymais patvirtintų karščiuojančio vaiko gydymo ir priežiūros gairių $[6,7,15]$, tačiau vieno Jungtinëje Karalystèje vykdyto tyrimo (2017) rezultatai atskleide, kad tik apie trečdalis (29,5 proc.) respondentų, dirbančių vaikų ITS, manė, kad tikètina, arba labai tikètina, kad jų skyriuje bus orientuojamasi į NICE gaires [18]. Yra atliktų tyrimų apie slaugytojų žinias ir įsitikinimus, teikiant pagalbą karščiuojančiam vaikui [13-14, 16-18], tačiau vis dar nèra bendrujų patvirtintų gairių, rekomendacijų, apibrèžiančių vienodą požiūrị i karščiuojantị vaiką, kuriomis galètų remtis visi pasaulio slaugytojai [19]. Šio tyrimo rezultatai parodè, kad tik dalis slaugytojų, dirbančių bendrojo profilio PSPS ir ITS, vertindami karščiuojančio vaiko būklę, vertina oro patekimą i plaučius, kraujotakos sutrikimus, odos ar liežuvio spalvą. Teikiant pagalbą karščiuojantiems vaikams Airijoje (2013), didesné dalis (66,0 proc.) tyrime dalyvavusių slaugytojų nurodè, kad žino, jog vaikams, kurie turi širdies ar kvėpavimo sutrikimų, karščiavimas yra labai pavojingas, todèl jiems būtina nedelsiant mažinti kūno temperatūrą [13]. Mūsų tyrimo rezultatai panašūs - didžioji dalis slaugytojų teigè, kad vaikui, turinčiam ịgimtą širdies ydą, imunosupresinės būklės, pagalbą teiktų nedelsiant - nustatytų gyvybei grèsmingus požymius, tikslų kūno temperatūros laipsnị, 
užtikrintų ramią ir vėsią $\left(+18{ }^{\circ} \mathrm{C}\right)$ aplinką bei kuo skubiau informuotų gydytoją.

Pradejjus karščiavimo gydymą, Izraelyje didžioji dalis (96,0 proc.) [8] ir Italijoje didesnè dalis (82,28 proc.) [20] slaugytojų pastebejjo, kad vaikų ligų gydytojai dažniausiai skiria antipiretiką paracetamolį. Viename iš Izraelyje atliktu tyrimų (2016), paracetamolio (acetaminofeno) vartojamają dozę $10-15 \mathrm{mg} / \mathrm{kg}$ nurodè skyrusios kas 6 val. 80,0 proc. tyrime dalyvavusių slaugytojų [8]. Mūsų atlikto tyrimo metu, tik apie penktadalis $(17,4$ proc.) $\mathrm{Z}$ ligonineje dirbančių slaugytojų kūdikio temperatūrą mažintų paracetamoliu (acetaminofenu) po $10-15 \mathrm{mg} / \mathrm{kg}$ kas 4-8 val., iki 5-ių dozių.

E. Salivanas ir kt., literatūros apžvalgoje apie karščiavimą ir karščiavimą mažinančių vaistų vartojimą vaikams, teigè, kad kai kurie tèvai, norėdami sumažinti aukščiau normos pakilusią vaiko kūno temperatūrą, naudoja kempinèles, suvilgytas alkoholiu [21]. Klinikinejje praktikoje toks kūno temperatūros mažinimo metodas nerekomenduojamas. Alkoholis, trinamas ị odą, palaipsniui absorbuojasi ị vaiko organizmą ir sukelia toksini poveikị [22]. Toks nemedikamentinis būdas, mažinantis pakilusią kūno temperatūrą, nèra efektyvus ir neretai vaikams sukelia stresą, diskomfortą ir drebulị, todèl kūno temperatūra nesumažeja, o dažnai pakyla dar aukščiau [23].

Nors yra patvirtintos NICE (2013) rekomendacijos, Izraelyje (2016) atliktas tyrimas atskleide, kad daugiau nei pusè (59,0 proc.) slaugytojų tėvus moko mažinti vaiko kūno temperatūrą, ji išstrinant kempinèle, geriausia - suvilgyta šiltu vandeniu $\left(38,0^{\circ} \mathrm{C}\right)$ [8], tačiau mūsų atliktame tyrime tik labai maža dalis (11,8 proc.) Y ligoninëje dirbančių apklaustụjų rekomenduotų tẻvams mažinti temperatūrą, ištrinant vaiko kūną kempinèle, suvilgyta alkoholiu.

Australijoje [19] ir Turkijoje [14] yra ugdymo programu tèvams, skirtų karščiuojančio vaiko gydymui bei žinių ir požiūrio ị karščiuojantị vaiką tobulinimui, tačiau trūksta literatūros pediatrijos slaugytojams: koks turi būti požiūris ị karščiuojantị vaiką, kaip tinkamai pasielgti, kai šalia nèra gydytojo, o vaikui kyla temperatūra, kokių žinių privalo turèti slaugytoja, kokie veiksmai nepriskiriami slaugytojo kompetencijai [19]. Slaugytojų žinių ir požiūrio ị karščiuojantị vaiką ugdymas yra labai svarbus, nes nèra sukurtų ir patvirtintų gairių, kuriomis galètų vadovautis pediatrijos skyrių slaugytojai [17].

Apžvelgus Izraelyje [8], Airijoje [13], Italijoje [20] ir San Diege [24] atliktų tyrimų rezultatus, pastebėta, jog slaugytojai turi pakankamai žinių apie temperatūros matavimą, vertinimą bei antipiretikų vartojimą. Trūksta žinių apie nemedikamentinius karččiavimą mažinančius būdus, febrilinius traukulius bei apie tai, kad tinkamu laiku sugirdytas antipiretikas turi reikšmès vaiko sveikimui. Žinios ir gebejimai yra labai svarbus aspektas, siekiant profesionaliai ir kokybiškai suteikti slaugos paslaugas karščiuojantiems vaikams. Kiekvieno slaugos veiksmo indikacijų ir kontraindikacijų žinojimas ne tik padeda išvengti komplikacijų, bet suteikia galimybę karščiuojantiems vaikams patirti mažiau nepatogumų.

\section{Išvados}

1. Didžioji dalis tyrime dalyvavusių slaugytojų dėmesi skiria karščiuojančio vaiko būklès nustatymui ir pokyčiu vertinimui, teikia informaciją karščiuojančio vaiko tėvams, žino antipiretikų skyrimo indikacijas ir dozes.

2. Mažiau nei pusė tiriamujjų, vertindami karščiuojančio vaiko būklę, vertintų kraujotakos sutrikimus, oro patekimą i plaučius, informuotų tèvus, kaip elgtis įvykus traukuliams, kaip atpažinti neblykštantį bèrimą.

\section{Literatūra}

1. Kèvalas R. Karščiuojančio vaiko klinikinis įvertinimas ir pradinè pagalba. Lietuvos gydytojo žurnalas,2012;2:49-52,53-55.

2. Kèvalas R. Karščiuojantis kūdikis ir mažas vaikas. Koks sprendimas būtų racionalus? Medicina, 2005;41(11):974-987.

3. Kèvalas R. Karštiniai traukuliai. Lietuvos gydytojo žurnalas, 2017;7:13-14.

4. Ray JJ, Schulman CI. Fever: suppress or let it ride? J Thorac Dis 2015;7(12):633-636. http://dx.doi.org/10.3978/j.issn.20721439.2015.12.28

5. Barbi E., Marzuillo P, Neri E, Naviglio S, Krauss B. Fever in children: pearls and pitfalls. Children 2017;4(9):81. https://doi.org/10.3390/children4090081

6 . Fever in under $5 \mathrm{~s}$ : assessment and initial management. Clinical guideline. NICE 2013.

https://www.nice.org.uk/guidance/cg160/resources/ fever-in-under-5s-assessment-and-initial-managementpdf-35109685049029

7. Feverish illness in children. Assessment and initial management in children younger than 5 years. Clinical guideline. NICE 2013.

https:/www.ncbi.nlm.nih.gov/books/NBK247907/

8. Abu Zubedeh M, Abu Mayaleh AR, Qtait M, Sayej S. Physicians and nurses knowledge, attitude, and practices in the management of childhood fever in Hebron pediatric clinics. J Health \& Social Policy 2016;31:105-120.

https://www.iiste.org/Journals/index.php/JHMN/article/ view/33717

9. Purssell E. Treating fever in children: paracetamol or ibuprofen? Br J Com Nurs 2013:7(6):316-320.

https://doi.org/10.12968/bjcn.2002.7.6.10477

10. Sahm LJ, Kelly M, Rømsing J. Knowledge, attitudes and beliefs of parents regarding fever in children: a Danish interview study. Family health 2016:105(1):69-73. https://doi.org/10.1111/apa.13152

11. Lietuvos Respublikos sveikatos apsaugos ministro $2019 \mathrm{~m}$. liepos 12 d. įsakymas Nr. V-828 "Dẻl Lietuvos medicinos normos MN 28:2019 "Bendrosios praktikos slaugytojas" patvirtinimo". 
https://www.e-tar.lt/portal/lt/legalAct/5aec6040a6db11e9b474 d97de297fe08

12. Lietuvos Respublikos sveikatos apsaugos ministro $2018 \mathrm{~m}$. gegužès 23 d. įsakymas Nr.V- 598 ,, Dèl Lietuvos Respublikos sveikatos apsaugos ministro $2004 \mathrm{~m}$. balandžio $8 \mathrm{~d}$. įsakymo Nr. V-208 "Dèl būtinosios medicinos pagalbos ir būtinosios medicinos pagalbos paslaugų teikimo tvarkos bei masto patvirtinimo" pakeitimo.

https:/www.e-tar.lt/portal/lt/legalAct/001d4e05e9311e89f00 $961 \mathrm{ca} 6 \mathrm{c} 2310 \mathrm{f}$

13. Greensmith L. Nurses' knowledge of and attitudes towards fever and fever management in one Irish children's hospital. J Child Health Care 2013; 17(3):305-316. https://doi.org/10.1177/1367493512461457

14. Baran G, Turan E. Investigation of the effect of the training on fever and febrile convulsion management given to pediatric nurses on their knowledge level. Int J Caring Sciences 2018;11(1):478-487.

https://pdfs.semanticscholar.org/6e39/3c40afbce04fb49ce203 e28fafd4580de0c.pdf

15. Ward MA. Fever in infants and children: pathophysiology and management. UpToDate 2015.

https://www.uptodate.com/contents/fever-in-infants-andchildren-pathophysiology-and-management

16. Martins M, Abecasis F. Healthcare professionals approach paediatric fever in significantly different ways and fever phobia is not just limited to parents. Acta Paediatr 2016:105(7):829-33. https://doi.org/10.1111/apa.13406

17. Kelly M, Sahm JL, Shiely F, O’Sullivan R, Brenner M, Larkin $\mathrm{P}$, mcCarthy S. The knowledge, attitudes and beliefs of carers (parents, guardians, healthcare practitioners, crèche workers) around fever and febrile illness in children aged 5 years and under: protocol for a qualitative systematic review. Syst Rev 2014:4(1):2-5. https://doi.org/10.1186/s13643-015-0021-7

18. Brick T, Agbeko RS, Davies P, Davis PJ, Deep A, Fortune PM Inwald DP, Jones A, Levin R, Morris KP, Pappachan J , Ray S, Tibby SM, Tume LN, Peters MJ; UK paediatric intensive care society study group (PICS-SG). Attitudes towards fever amongst UK paediatric intensive care staff. Eur J Pediatr 2017;176(3):423-427.

https://doi.org/10.1007/s00431-016-2844-1

19. Edwards H, Courtney M, Wilson J, Monaghan S, Walsh A. Fever management practices: what pediatric nurses say. Nurs Health Sc 2001;3(3):119-130.

https://www.ncbi.nlm.nih.gov/pubmed/11882188

https://doi.org/10.1046/j.1442-2018.2001.00083.x

20. Raffaeli G, Orenti A, Gambino M, Pever Rios W, Bosis S, Bianchini S, Tagliabue C, Esposito S. Fever and pain management in childhood: healthcare providers' and parents' adherence to current recommendations. Int J Env Res Publ Health 2016;13(5):499.

https://doi.org/10.3390/ijerph13050499

21. Sullivan JE, Henry CF. Fever and antipyretic use in children. Pediatrics 2011;127(3):580-587. 22. Meremikwu M, Oyo-Ita A. Physical methods versus drug placebo or no treatment for managing fever in children. Cochrane Database Syst Rev 2003;(2):CD004264.
https://doi.org/10.1002/14651858.CD004264

23. Clarke P. Evidence-based management of childhood fever: what pediatric nurses need to know. J Ped Nurs 2014:29(4):327-375. https://doi.org/10.1016/j.pedn.2014.02.007

24. Templet, AT. Reducing antipyretic use for low-grade fevers in otherwise healthy children. Doctor of nursing practice final manuscript. University of San Diego 2015.

https://digital.sandiego.edu/dnp/32/.

\section{NURSES' MANAGEMENT OF PAEDIATRIC FEVER S. Kostyliovienė, L. Mozūraitytė, A. Vaškelytė, D. Grinkevičiūtè, R. Adomaitienè}

Keywords: child, fever, nurses' activity, emergency aid in fever. Summary

Nurse is one of the most important health care member in the management of febrile child. Nurse is a person which has to know as well as to be able to evaluate the status of febrile child, to notice the changes, to provide professional and qualitative care, to give the correct information to the caregivers, to involve the parents into the child's care, to know the possible methods of nonmedical treatment, to know safe dosage and possible side effects of antipyretics. Appropriate knowledge and professional management can lead to better and quicker recovery of a febrile child.

The aim was to reveal nurses' knowledge and practice in management of a febrile child.

The study was conducted in 2018.11.07-2019.12.03, in the selected units of $\mathrm{X}$ university, $\mathrm{Y}$ clinical and $\mathrm{Z}$ regional hospital, by means of nurses' anonymous survey. All nurses, who are managing children in Intensive care units and Emergency rooms of those hospitals were invited to participate in the study.105 questionnaires were handed to the participants of the study, the return rate was $78.09 \%$ (82 questionnaires).

Results. The study results showed that bigger part of nurses focuses on the changes in the condition of a febrile child - breathing, body temperature, consciousness, dehydration, gives information to the parents of a febrile child, knows about the dosage of antipyretics according to the age and weight, but less than half of the nurses would assess hemodynamic disorders, air intake, inform the parents about their possible actions in case of seizures, how to recognize hemorrhagic rash, a small part would advise to sponge the febrile child with alcohol. Majority of the nurses from ER knows and recommends the correct fluid intake according to the child's age, would inform about the signs of the worsening condition of the child, would ask the parents, if they understood the information, only a half would assess the condition of febrile child, skin and lips color, consciousness, would inform in detail about correct dosage of antipyretics, a small part would advise to sponge a child with alcohol. Majority of the nurses from ICU while assessing the life threatening signs in febrile child's condition would pay attention to breathing and circulation and advise parents the correct dose of antipyretics according to the child's age and the use of fluid intake, would inform about fluid requirements according to the child's age, but less than a half would assess difficulties in breathing consciousness, nobody would advise to sponge the febrile child with alcohol.

Correspondence to: silva.kostylioviene@go.kauko.lt

Gauta 2019-10-17 